
Not for reproduction, distribution or commercial use.

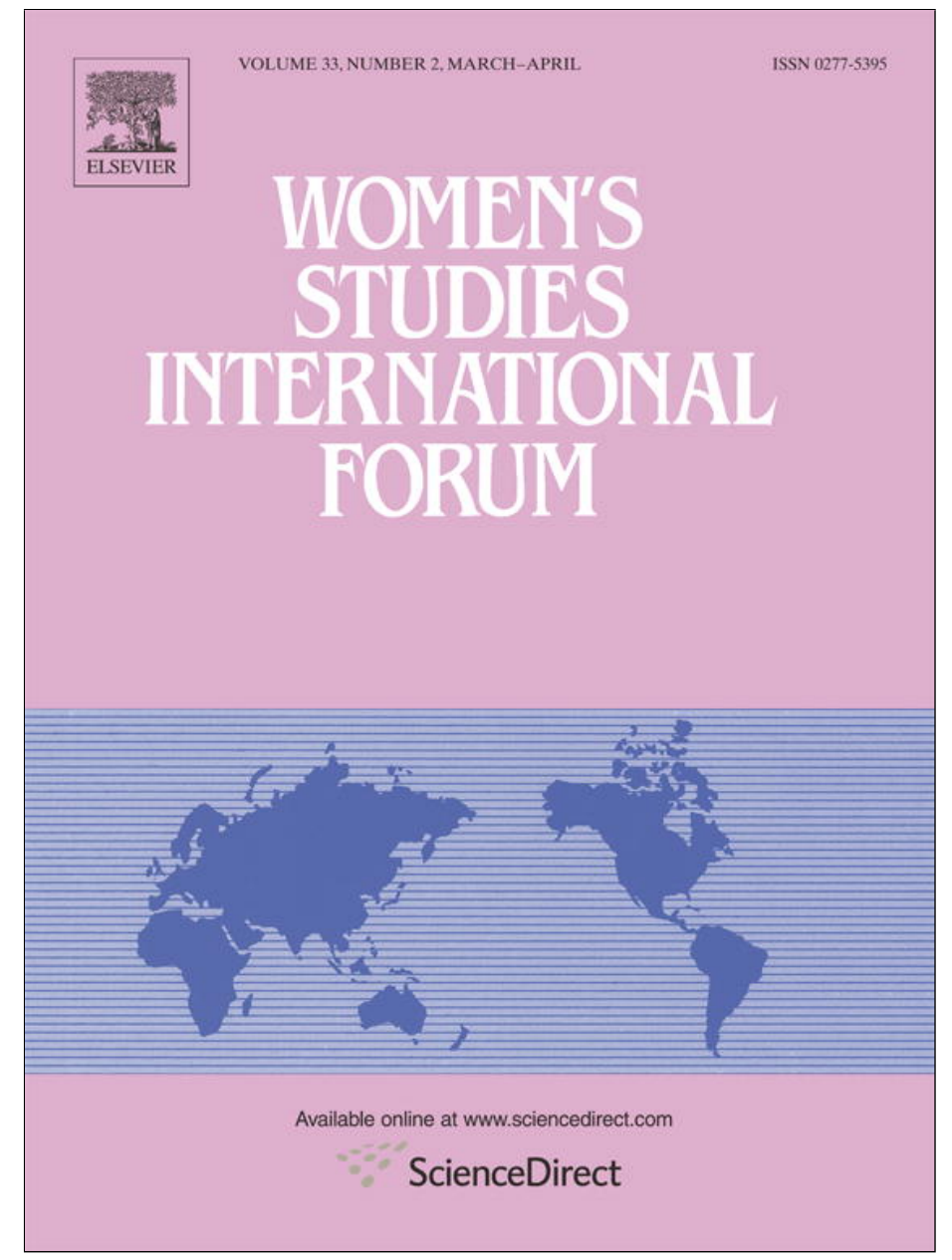

This article appeared in a journal published by Elsevier. The attached copy is furnished to the author for internal non-commercial research and education use, including for instruction at the authors institution and sharing with colleagues.

Other uses, including reproduction and distribution, or selling or licensing copies, or posting to personal, institutional or third party websites are prohibited.

In most cases authors are permitted to post their version of the article (e.g. in Word or Tex form) to their personal website or institutional repository. Authors requiring further information regarding Elsevier's archiving and manuscript policies are encouraged to visit:

http://www.elsevier.com/copyright 


\title{
The price of success? The experiences of three senior working class female academics in the $\mathrm{UK}^{\text {is }}$
}

\author{
Kate Hoskins \\ Department of Education E Professional Studies, King's College London, UK
}

\section{A R T I C L E I N F O}

Available online 13 January 2010

\begin{abstract}
S Y N O P S I S
This paper explores how gender and class shape the constructions, perceptions and experiences of career success for three senior female academics, all of whom come from a white, working class background, paying attention to whether they reported any 'price' for their academic success. The paper is divided into four sections; first, there is a brief overview of what is known about working class women's experiences of higher education. Second, the paper outlines the methodological approach informing this research. Third, the paper explores the complexity of success. Fourth, some of the costs that my respondents have paid for their career success are discussed.
\end{abstract}

(c) 2009 Elsevier Ltd. All rights reserved.

\section{Working class women and higher education}

Since the Second World War the number of female students participating in HE and moving on to work in HE in the UK has gradually increased (Coats, 1994). This increase centres around three factors; first, policy changes, such as the 1944 Education Act, which allowed some working class girls access to an academic school curriculum via the eleven plus examination (Matheson \& Grosvenor, 1999). Second, the expansion of HE during the 1960s created additional capacity (Brooks, 1997). Third, the demands of the post war economy, where "the growth of white-collar and professional occupations required the recruitment of female labour" contributed to the increase of female participation in HE (Brooks, 1997: 16). These three factors were circumscribed to some extent by dominant gendered discourses which prescribed some academic disciplines (e.g. education and nursing) and forms of employment (e.g. secretary, teacher and nurse) as more compatible with femininity and other disciplines (e.g. law and natural sciences) and professions (e.g. lawyer, pharmacist and physician) as less so. In explaining the increasing participation of females in higher education in the post Second World War period, Deem (1995: 31) points out that;

changes in the education of women since 1944 have usually been accompanied by changes in general social

\footnotetext{
th This paper would not have been possible without the comments, feedback and encouragement provided by Professor Meg Maguire.
}

policy, and those changes have been closely linked to the needs of the economy and to prevailing ideologies about women's role in society.

To accommodate these changes the state at that time emphasised a 'dual role' for women, encompassing paid work and family commitments (Deem, 1995) and consequently "encouraged women into education and training" (Brooks, 1997:16). State welfare provisions were increasingly made available (for example childcare) thus enabling

women to participate more fully in the labour market, albeit in segregated sectors. As a result, the 1960s saw an upsurge in women students' entry to universities (Brooks, 1997: 16).

Yet in the UK by 1989 , women still only made up $25 \%$ of the cohort attending university (Coats, 1994). Delamont (2006: 179) asserts that "women are newcomers in higher education". In the mid 1990s Acker (1994: 125) noted that,

Women are a minority [...] among full time teachers and researchers in UK universities and better represented in lower than higher ranks.

Overall, the rates of women participating in undergraduate courses in higher education increased during the latter part of the twentieth century and the number of women in academic posts rose from $9 \%$ to $36 \%$ of the workforce between 
1995 and 2005, yet many of these posts remained clustered in the lower ranks (Higher Education Funding Council for England, HFCE, 2006).

The Association of University Teachers (AUT) research demonstrates that as a group, women working in the academy generally earn less and have less time to undertake research when compared to their male counterparts (AUT, 2004). Yet some women have gained access to senior posts. Warwick's (2004: 2) research shows that in 2004,13\% of all professors in the UK were women, a "considerable improvement" on the $8.5 \%$ of women professors in $1995 / 6$. Whilst there has undoubtedly been progress, statistics outlining the position of women in the academy still make bleak reading when we consider that in the UK women;

hold $42 \%$ of full time academics posts (including both teaching and research), whereas they account for only $27 \%$ of senior lecturers... and $12 \%$ of vice-chancellors. The figures are even more revealing if we look at different disciplines; whereas $24 \%$ of education professors are women, only $2 \%$ of physics professors are women, and there are none at all in civil engineering (Universities UK, 2004 cited in Bagilhole, 2007: 23).

Thus, women academics as a group are less represented in senior positions than their male colleagues even in 'feminised' disciplines such as education. Drawing on research undertaken by the Higher Education Statistics Agency, Bagilhole (2007: 23) argues that "women are $33 \%$ more likely than men to be employed on fixed-rate contracts and 550\% less likely to be professors". She claims that universities, as employers, have "signally failed to make enough progress in promoting women [...] which sends a bad message to the next generation" (Bagilhole, 2007: 23). As Brooks (1997: 19) argued over a decade ago "the appointment and promotion of women academics to senior positions has not kept pace with the recruitment of women students". This position remains relatively unchanged. Thus the marginal representation of female academics at a senior level has persisted into the twenty first century.

Those women from working class backgrounds who navigated the HE terrain and subsequently gained high status employment in the academe are a relatively small group. Research that documents the experiences of these objectively successful senior female academics has only been undertaken relatively recently (Mahony \& Zmroczek, 1997; Reay, 2001; Hey, 2003; Maguire, 2005). This literature highlights the sense of ambivalence with which many of these women view their career success and class position in the academy. For example, Mahony and Zmroczek (1997: 1), both white female academics from working class backgrounds, wrote of their struggle over their class identity after being appointed academic posts:

though both of us were told repeatedly that by virtue of our education and our 'position in the labour market' we were not working class, we did not feel middle class nor believe that we had necessarily 'gone up in the world'.

In making the transition into the academy some women may be faced with the contradictions of their class identity. They are from working class families but they now work in middle class professional occupations, yet they may still feel and identify themselves as being working class. The tensions that can be created when working class people move into professional occupations was captured in the work of Williams (1961: 343) over forty years ago when he noted that "we are still not sure whether the determining factor, in our membership of a social class, is our birth or our adult work". For some working class female academics "mere entry into the academy [...] will not automatically transform class experiences and allegiances" (Morley, 1997: 116). Indeed, Mahony and Zmroczek (1997: 5) struggled against being cast as middle class, noting "feelings of anger and guilt at being part of the academy, at the same time as being excited by intellectual work". These conflicting feelings of anger and guilt are perhaps a result of the view that "not being middle class is certainly valued in many working class social groups" (Skeggs, 1997:11). Skeggs (1997: 11) suggests that within family and friendships groups "careful monitoring for pretensions often takes place", which she suggests, is evident in "the long standing clichés, such as 'too big for your boots', and 'full of airs and graces"'. Gardner (1993: 54) argues that many working class academics "learn very early in their careers that their life-style, general interests, and work are largely incomprehensible to their families". Thus, some female academics from working class backgrounds may feel "uncomfortable and out of place, as 'outsiders within' or 'insiders-out"' (Wright et al, 2007: 153) at both home and work. The tension created between work and family may require a form of identity balancing act where on one hand they enjoy the academy's predominantly white middle class activities (i.e. research), yet on the other hand, value their working class background.

A sense of displacement emerges from these autobiographical accounts and is arguably manifested in these senior academic women reporting that they feel 'lucky' to be in their current positions (Mahony \& Zmroczek, 1997). Mahony and Zmroczek (1997: 5) argue that

women who have gone through higher education often see themselves as being required to continue an ethic of service to others less 'lucky' than themselves.

This in turn can contribute to female academics from working class backgrounds feeling insecure about their positions, or 'feeling like frauds' (McIntosh, 1985), never quite belonging, always needing to repay the academy (Smulyan, 2004). As Morley (1997: 115) points out, "the academy with its claims to authority and knowledge production, provides perfect preconditions for feelings of fraudulence". Mahony and Zmroczek (1997: 5) argue that in an attempt to overcome these feelings of inadequacy, the female academic from a working class background tends to "overwork" in an attempt to honour this "fulfilment of the service ethic". Gardner (1993: 16) concurs noting;

Working class women academics are more likely to accept heavy teaching loads and committee work because of the psychological toll of crossing gender and class barriers.

In sum, the literature reported here suggests that there are emotional costs involved for some working class women who obtain senior posts in HE settings. 


\section{Methods}

The experiences of three senior academics' constructions of their careers in HE were qualitatively investigated via in-depth interviews, informed by a life history approach (Goodson \& Sikes, 2001). The data drawn on here was collected as part of a larger study conducted with senior female academics who all work in English Universities. The data for the larger study was gathered via an extended semi-structured interview (each interview lasted approximately $11 / 2 \mathrm{~h}$ ) with six women from white working class backgrounds. The three respondents included in this paper were selected on the basis of their shared employment status (they are all professors) - the three respondents omitted from this paper are either senior lecturers or readers. The three respondents included in this paper were educated in the 1950s; and all three trained as state sector primary or secondary teachers, ${ }^{1}$ moving into HE as second careers (Table 1 ).

A qualitative approach offers a snapshot in time; it is historically grounded and the views expressed are often fluid and subject to change as the respondents construct and reconstruct their experiences sometimes in the process of being interviewed. Thus, the data presented in this paper is partial and incomplete; an insight into a story in progress rather than a final or conclusive account.

Interviewing academics in an attempt to explore aspects of their life history requires trust and confidentiality, and the quality of the data generated will be influenced by the quality of the research relationship. If we accept that "knowledge is power and knowing something about someone puts the researcher into a potentially powerful situation" (Goodson \& Sikes, 2001: 91), the need to be ethically rigorous is paramount. To address the issue of research ethics, I assured my cohort of anonymity via the use of pseudonyms, I changed any details that might reveal their identity and I reiterated their right to withdraw from the research process at any time (Kirsch, 1999).

My class position also raises ethical questions; I have a working class background which shaped the interview process and relationship through the identification of shared norms and values. Indeed, my values, views, perceptions of the world and my embodied self influenced the questions I asked, the leads I followed up on, or not, and subsequent choices of data representations I have made, which is a limitation to this study. There were some further limitations to this study; the small sample size and the lack of diversity and the lack of discipline difference within the sample.

I also acknowledge that the respondent's religion, sexuality and ethnicity are likely to impact upon their experiences, constructions and perceptions of success, but these issues were not explored in detail in the interviews. These factors shape the findings offered here and suggest areas for further study.

Table 1

Sample details.

\begin{tabular}{ll}
\hline Name & Role \\
\hline $\begin{array}{l}\text { Nancy } \\
\text { Grace }\end{array}$ & $\begin{array}{l}\text { Professor. Previously worked as a school teacher and a FE lecturer. } \\
\text { Dee }\end{array}$ \\
& $\begin{array}{l}\text { Professor. Previously worked as a primary school teacher and a } \\
\text { researcher. }\end{array}$ \\
\hline
\end{tabular}

In approaching the situated experiences of women in the academy who come from working class backgrounds, it is important to locate the way in which class is conceptualised in this paper. Through attending conferences and informal networking I made contact with senior academic women who I was aware identified themselves as being from working class backgrounds and who were willing to be interviewed. The respondents' class positions were supported in the interview process. Yet I acknowledge that what is taken to mean the 'working class' is contested (Ball, 2003); it is not a homogenous group, but rather is increasing fractured and differentiated. The older, yet still useful work of Rubinstein (1969: 10) problematises social class generalisations, noting that

the working class itself was not a single homogenous mass. It was made up of numerous degrees and grades which shaded into one another.

My respondent's working class backgrounds reflected this diversity. For example, they all reported somewhat differing family values, forms of education provision, employment opportunities and class cultural norms, of what it means and has meant to them to be working class. For example they all reported different degrees of parental involvement in their education progression; some parents were encouraging and knowledgeable, others relied on the school and the teachers (Jackson \& Marsden, 1962). Yet there were similarities in their constructions of being working class, most notably, their experiences of social mobility as they all were the first in their families to participate in HE. A dominant thread running through the interviews was the ways in which they viewed success as highly complex and constructed their success as being influenced by their class and gender position. The paper now explores these constructions.

\section{Success - a complex concept}

There is a contested set of meanings around what is meant by, and understood to constitute HE career success. Whilst 'success' can be represented in an objective way as a feature of appointment, promotion and status, it also has a subjective dimension related to emotions and beliefs about self-efficacy (Reay 1996). So ‘success' for a senior female academic might mean achieving high status or a promotion-based goal, or it might mean avoiding failure. Individuals may well hold subjective and objective constructions of success simultaneously; some objectively successful senior working class academics may well feel ambivalent about their success and still recall failures more regularly than success. Gender and class background might invade and shape these women's constructions of their success:

Lack of comprehension, at crucial stages in one's education, can mean a re-evaluation of aspirations and ambitions, as working class women learn to settle for second best (Morley, 1997: 118).

Yet undoubtedly many academics from working class backgrounds experience pleasure and fulfilment from the 
journeys they have taken from their childhoods to the academy (Mahony \& Zmroczek, 1997); for example, the pleasure of hard work, of being able to undertake research and the satisfaction of assisting in their students' success, issues which are discussed below.

In the interviews all three of the respondents' highlighted the complexity of success, noting that it is a tricky concept and tensions and ambivalence surround their constructions, perceptions and experiences of success, some of which are related to their working class backgrounds. Dee wove her experiences of progression and promotion as an academic into her experiences of family life, stressing the importance of both attributes in her constructions of success.

Success is a difficult thing I think. To be successful, you have to look at a person in the round and you know if you put everything into your career at the expense of your personal and social relationships, then I'm not sure I'd see that as a success... success is about recognition and being valued... but then that's problematic I think too (Dee).

Dee made it clear that whilst her job was very important to her, so was having a balanced life and as such, family and friends are integral to her and time spent with them is an important part of her success. Sturges (1999: 248) similarly found in her research that women managers were more likely to view a successful career "as just one part of the success they wanted to achieve in their lives as a whole" and consequently they were "more inclined to talk about an interest in succeeding in other parts of their life" alongside their careers. Yet whilst on one hand achieving balance between the different spheres of her life was a defining aspect of Dee's view of success, on the other hand she works incredibly hard, indeed overworks, much of the time; she told me "I can work really really hard [...] but I've always been a workaholic". Dee offered me her explanation of this commitment to her work, pointing out that,

if you're like most of us working class girls who made good in academia are, we're incredibly conscientious, responsible and hard working.

Gaining recognition and being valued are also elements of Dee's understanding of success, but this is problematic because according to her "too much success and recognition are innately corrupting”. Dee has observed that 'recognition' has led some of her middle class colleagues to tend to talk "endlessly about how bright and intelligent their colleagues and by inference they themselves are". She attributes her reluctance to be positioned in this way to her working class upbringing, where an emphasis was placed on equality not superiority; she explained "I was brought up to believe we are all equal and that to be treated any differently is unfair". Perhaps Dee may be concerned about being perceived as getting "too big for [her] boots" (Skeggs, 1997: 11). Yet according to Dee "when you become a university professor you start getting treated better but as if you are innately better". She is anxious to resist being positioned in this way, but notes that "it's so seductive to believe the hype". Thus, Dee is engaged in a balancing act between "holding onto original community values" whilst occupying a position of institutional power.
Nancy's narrative also captured the ambivalence of career success;

Objectively I am a success. On paper. Anyone who looks at me would say that I'm a successful woman. I am successful in my career because I have reached a very senior level. My salary reflects that. I am successful in terms of what it means to be an academic because I tick the boxes; I publish, I do research, I have research students. So I am objectively speaking a success story. But, subjectively, the price has been very high... Subjectively within myself I recognise success for what it is and it's a hollow crown so I don't get hung up about it.

Nancy recognises her own objective success in that she "ticks the boxes" of clearly defined academic success (publishing, researching etc). Conceptualising her objective academic success as a 'hollow crown' suggests she is ambivalent about it, perhaps she experiences it as an illusion; the smoke and mirrors of career status is an overrated reality. Morley (1997: 115) draws attention to the Groucho Syndrome "which suggests that everything we acquire becomes devalued once it belongs to us" - this perhaps offers some insight into Nancy's subjective understanding of her success. Nancy's understanding of her career success is fraught with complex identity negotiations, which are not easily resolved - hinting towards the costs she reported for her academic success. Before I explore the costs of the respondent's success, attention is paid to the benefits.

\section{The benefits}

The respondents had experienced 'gains' as a result of their objectively successful careers in the academy. They discussed some or all of the following five benefits; writing, student progression, personal pleasure, researching and autonomy at work. Nancy experienced success in relation to her ability to support her students; she explained, "I see success in my students doing well... That's a feeling of my success". This expression of success might in part be borne out of a desire to help "those students in whom we see ourselves" (Mahony \& Zmroczek, 1997: 5). It may also reflect Nancy's commitment to the progression of all her students, borne from her desire to 'give something back' to the education system. Dee similarly believes that giving back "is really important", but felt that this is "not part of the culture of academia". She now finds that as a professor and consequently in a position of relative power, she spends a lot of time helping others to progress within the academy, something she feels working class female academics tend to do. Dee explained,

what I do is I think what a lot of women particularly from my background do... you know if people ask for help, if people want mentoring, if people want support, if I'm asked to do something that's a contribution to the wider academic community, then I find it very difficult to say no.

Nancy and Dee's construction of deriving success from working with students could indicate that they are fulfilling a traditional feminine caring role, possibly to the detriment of their own career success; time spent with students is time that could be spent writing in the increasingly competitive 
academy. Perhaps an element of Nancy and Dee's choice to tell me about this aspect of their constructions of success is produced through the interview process. Hammersley (2003: $120)$ argues that in the process of an interview, interviewees may be "driven by a preoccupation with self-presentation and/or with persuasion of others". As Maguire (2005: 429) points out "all interviews are social occasions, performances by the interviewer as much as the interviewee".

Nancy also valued being able to undertake academic research and writing as a career;

The awful thing is I've always enjoyed studying and it's like, it sounds really stupid but I hate starting writing something. But once I'm in there and I've got something it's like problem solving, juggling it together and making it work. And at that point I really love it; it's really interesting and it's really self indulgent and it's about like the life of your mind, like problem solving....and aren't I lucky to be able to do it.

This view concurs with that of Mahony and Zmroczek (1997: 5), who note that some women academics are "excited by intellectual work". Similarly, Grace told me "I like reading. I love writing. I think I always have really, really enjoyed writing". Like Nancy and Grace, Dee's 'gains' are also couched in terms of her own personal enjoyment, fulfilment and freedom in her work; she explained,

It's very interesting because the people at my university who get all the hard work, so most of the teaching on the PGCE's, the Masters, you know all that administrative teaching load, all want to retire... but those of us who are professors, you know regardless of our backgrounds...want to go on being professors, we want to go on doing our research.

Dee's narrative raises a question about status and hierarchy; the further up the academic ladder an individual goes and the 'better' it gets, arguably the harder it may become to step off. Perhaps this experience is bound up in the "prevailing culture of individualism and competitiveness which has given free rein to an end-of-millennium capitalism" (Reay, 1997: 23). Reay (1997: 23) adds that "competition and individualism are all about hierarchy and pecking order". Being successful in an objective sense improves an individual's capacity to be autonomous, choosing research over teaching and administrative duties.

\section{Success at what cost?}

The costs reported here are generational and contextual; that is, they are specific to some working class girls educated in the late 1950s and 1960s. For Nancy the cost was constructed in terms of her own success, to the detriment of her peers at school; for Grace it was gendered, involving balancing work and family life. Taking each in turn, according to Nancy,

the price of my success is costed against the other 36 children in my primary school, who didn't get what I got. The price of my success is the price of their failure... There were four rows of us and all of the back row couldn't read. The price of my success was the price paid by those children sitting in the back row who never learnt to read at primary school.

Nancy constructs her success as relative to the failure of other working class children and recognised that the attention and extra coaching (sponsorship) she received at school was to the detriment of others' education. Nancy reported that the sense of guilt she felt emerged as a driver influencing her decision to work in education in order that she might 'give something back'. Nancy's success reflects the fact that "selection led to the under-education of many working class children" (Brine, 2006, p.433). As Evans (1995: 61) argues:

...for the great majority of English children in the 1950s and the 1960s the eleven plus was the first and in many cases the last public examination that they took.

The competitive and hierarchical nature of the school system, compounded by selection procedures, meant that school success was possible for only a few. For the majority of working class children, such selection served as "a gentle shaking of the sieve, with now and again one or two big jerks" (Jackson \& Marsden, 1962: 231). Many children from working class backgrounds who did not pass the eleven plus and therefore did not attend grammar schools "were being pushed out of the sieve in big numbers" (Jackson \& Marsden, 1962: 231).

For Grace the price has been gendered, involving balancing work and family life. Grace recognised that she had paid some price for her success because of her family commitments. She told me;

It's a kind of complex mixture of the price of being a woman and having children and having a family. I think that's suffered. I think it's impossible to be a high achieving professional woman and it not to impact on your kids and your family in terms of paying attention to them.

Whilst Grace has experienced a successful academic career, she feels that in the process, her children have paid a price. Grace experienced a dilemma facing many working women negotiating a balancing act between the demands of their careers and those resulting from the needs of providing care and domestic support for a husband and/or family (Mavin \& Bryans, 2002). Smulyan (2004: 229) argues that:

the conception of balancing multiple roles, each of which is constructed within a different (and sometimes competing) discourse is, at best, overly optimistic, and, at the least, overly simplified.

For Grace, balancing work and family needs was at times a cause of tension and stress, suggesting that tensions between family and career demands can be a factor for professional women, partly due to persisting dominant ideologies about the role of women as needed within the home (Spencer, 2005).

\section{Discussion}

This paper has examined some of the perceptions of three senior female academics from white, working class 
backgrounds, paying attention to whether they reported any 'price' for their academic success. I agree with Gladwell (2008: 19), who argues;

People don't rise from nothing. We owe something to parentage and patronage... The culture we belong to and the legacies passed down by our forebears shape the patterns of our achievements in ways we cannot begin to imagine. It's not enough to ask what successful people are like, in other words. It is only by asking where they are from that we can unravel the logic behind who succeeds and who doesn't.

In terms of unravelling the role of class background in my respondent's career success, I conclude that as a result of their education (not discussed here) and subsequent careers all of the respondents occupy a transitional class position - that is they now occupy middle class spaces, although for all of them, this was only in terms of their professional occupation. Gardener (1993: 55) has described working class female academics as "marginal members of two cultural worlds". Such "a transitional class position is fragile and emotional" (Brine, 2006, p.443). Consequently, Brine (2006, p.443) argues that an "unproblematic shift of class identity was, and is rare; a continual negotiation of a shifting transitional class position is far more likely"; this was certainly the case for my respondents. Alongside class, the paper also explored the role of gender in the respondents' academic success. Being female was a factor in terms of the limitations it placed on Grace. The white working class women in this study were all educated in the post Second World War period and subject to the set of discourses and ideologies about classed femininity at that time (Spencer, 2005); these factors influenced Grace's experiences.

In terms of the paper's attempt to gain a greater understanding of the cost of the respondent's success, it emerged that there is a classed and gendered, generational price, underpinning these women's perceptions of their success as a result of the particularities embedded within the historical context of their education and subsequent employment opportunities in 1950s and 1960s England. As Gladwell (2008: 137) argues

The sense of possibility so necessary for success comes not just from inside us or from our parents. It comes from our time: from the particular opportunities that our particular place in history presents us with.

A further finding is the way in which the price of success was constructed similarly for the respondents in both subjective and objective ways. All of the respondents reported that either they were not worthy of their success, or that they felt like frauds, interlopers in both grammar school and the academy. But these women are undeniably successful, so why do they construct themselves in self-depreciating ways? It could be partly related to the performative nature of interviews, which serves to produce these women in particular ways. Or it may be that they, similarly to Reay (1997: 27), are engaged in a process of,

reconciling what I have become with what I was, while simultaneously trying to carve out a self that I can feel at ease with.
As such, this paper has highlighted the ambivalence surrounding all the respondents' constructions of the price they have paid for their success in relation to the positions they have attained in the academy.

Clancy (1997: 48) reflects that women academics with a working class background, in the process of '“bettering' ourselves through education [...] are simultaneously "betraying' our roots, our culture". That in the process of "moving out of one's class one is implicitly criticising it: this is good enough for you, but not for me" (Clancy, 1997: 48). The cost of my respondent's success is, in part, the difficulty of managing a desire not to be, and not to be seen as being, better than those they have 'left behind' in class terms; a disavowal of being superior, yet underneath a lingering sense of not feeling worthy. Thus, the respondents' social class, gender and the historical specificity of their lives has shaped and continues to shape their experiences and constructions of both subjective and apparently objective success within the academy.

\section{Endnotes}

${ }^{1}$ It is interesting that the respondents were all primary school teachers, and confirms the view that teaching has long been considered a suitable and respectable job for women, particularly middle class women although working class women were also encouraged (Maguire, 1997). As Morley (1997, p.117) notes that, "it is no coincidence that many working class women access the academy initially through teacher $[. .$.$] education".$

\section{References}

Acker, Sandra (1994). Gendered education. Buckingham: Open University Press.

Association of University Teachers. (2004). The unequal academy - UK academic staff 1995-96 to 2002-03. London: AUT Publications.

Bagilhole, Barbara (2007). Challenging women in the male academy: Think about draining the swamp. In Pamela Cotterill, Sue Jackson, \& Gayle Letherby (Eds.), Challenges and negotiations for women in higher education by Cotterill The Netherlands: Springer.

Ball, Stephen J. (2003). Class strategies and the education market: The middle classes and social advantage. London: RoutledgeFalmer.

Brine, Jacky (2006). Tales of the 50-somethings: Selective schooling, gender and social class. Gender and Education, 18(4), 431-446.

Brooks, Ann (1997). Academic women. Buckingham: Open University Press.

Clancy, Kim (1997). Academic as anarchist: Working-class lives into middleclass culture. In Pat Mahony \& Christine Zmroczek (Eds.), Class matters: 'Working Class' women's perspectives on social class London: Taylor \& Francis.

Coats, Maggie (1994). Women's education. Buckingham: Open University Press.

Deem, Rosemary (1995). State policy and ideology in the education of women 1944-1980. In Liz Dawtrey (Ed.), Equality and inequality in education policy Clevedon: Multilingual Matters.

Delamont, Sara (2006). The smell of sweat and rum: authority and authenticity among capoeira teachers' in Ethnography and Education, vol. 1, No. 2. (pp. 161-175) Issue.

Evans, Mary (1995). Culture and class. In Maud Blair, Janet Holland, \& Sue Sheldon (Eds.), Identity \& diversity Clevedon: Multilingual Matters.

Gardner, Sandra (1993). What's a nice girl like you doing in a place like this? In Michelle Tokarczyck \& Elizabeth Fay (Eds.), Working class women in the academy Amherst: University of Massachusetts Press.

Gladwell, Malcolm (2008). Outliers. Hachette Book Group: USA.

Goodson, Ivor, \& Sikes, Pat (2001). Life history research in educational settings: Learning from lives. Buckingham: Open University Press.

Hammersley, Martyn (2003). Recent radical criticism of interview studies: Any implications for the sociology of education? British Journal of Sociology of Education, 24(1), 119-126.

Hey, Valerie (2003). Joining the club? Academia and working-class femininities. Gender and Education, 15(3), 319-335.

Higher Education Funding Council (HFCE). (July 12, 2006). Equality gap narrowing in higher education URL: http://www.hefce.ac.uk/News/ hefce/2006/work force.htm, accessed March 2007. 
Jackson, B., \& Marsden, D. (1962). Education and the working class: Some general themes raised by a study of 88 working class children in a Northern industrial city. London: Routledge.

Kirsch, Gesa A. (1999). Ethical dilemmas in feminist research: The politics of location, interpretation and publication. Albany : State University of New York Press.

Maguire, Meg (1997). Missing Links; Working-Class Women of Irish Descent. In Pat Mahony \& Christine Zmroczek (Eds.), Class Matters: 'Working Class' Women's Perspectives on Social Class London: Taylor\&Francis.

Maguire, Meg (2005). Not footprints behind but footsteps forward': Working class women who teach. Gender and Education, 17(1), 3-18.

Mahony, Pat, \& Zmroczek, Christine (1997). Why class matters. In Pat Mahony \& Christine Zmroczek (Eds.), Class matters: 'Working Class' women's perspectives on social class London: Taylor\&Francis.

Matheson, David, \& Grosvenor, Ian (Eds.). (1999). An introduction to the study of education London: David Fulton Publishers.

Mavin, Sharon, \& Bryans, Patricia (2002). Academic women in the UK: Mainstreaming our experiences and networking for action. Gender and Education, 14(3), 235-250.

McIntosh, Peggy (1985) Feeling like a Fraud. This paper was presented at a Stone Center Colloquium in April 1984.

Morley, Louise (1997). A class of one's own: women, social class and the academy. In Pat Mahony \& Christine Zmroczek (Eds.), Class matters: 'Working Class' women's perspectives on social class London: Taylor\&Francis.

Reay, Diane (1996). Insider perspectives or stealing the words out of women's mouths: Interpretation in the research process'. Feminist Review: Speaking out: Researching and representing women, vol. 53. (pp. 55-71).
Reay, Diane (1997). The double-bind of the 'working class' feminist academic: The success of failure of the failure of success? In Pat Mahony \& Christine Zmroczek (Eds.), Class matters: 'Working Class' women's perspectives on social class London: Taylor\&Francis.

Reay, Diane (2001). Finding or losing yourself?: Working-class relationships to education. Journal of Education Policy, 16(4), 1-14.

Rubinstein, David (1969). School attendance in London, 1870-1904: Social history. Hull: University of Hull.

Skeggs, Beverley (1997). Formations of class $\mathcal{E}$ gender. London: Sage Publications Ltd.

Smulyan, Lisa (2004). Redefining self and success: Becoming teachers and doctors. Gender and Education, 16(2), 226-245.

Spencer, Stephanie (2005). Gender, work and education in Britain in the 1950s. Palgrave Macmillan: Basingstoke.

Sturges, Jane (1999). What it means to succeed: Personal conceptions of career success held by male and female managers at different ages. British Journal of Management, 10, 239-252.

Warwick, Diane (2004). Women and leadership: A higher education perspective a speech given at the Barbara Diamond Memorial Lecture, University of Westminster on 17 March 2004 http://www.universitiesuk. ac.uk/speeches/ show.asp?sp=64, accessed March 2007.

Williams, R. (1961). The long revolution. London: Chatto and Windus.

Wright, Cecile, Thompson, Sonia, \& Channer, Yvonne (2007). Out of place: Black women academics in British universities. Women's History Review, 16(2), 145-162. 